\title{
Soldiers and Politicians in the American Civil War
}

\author{
By Marcus Cunliffe
}

Prof. Marcus Cunliffe, the English historian and biographer of Georg Washington, gave a lecture at the Otnas conference, where he discussed the tensions and the power struggle between the generals and the politicians in the Civil War. This lecture is printed here for the first time.

We cannot do without generalizations. Our minds need something to hang on to; and categories are easiest to hang on to when they can be expressed as a dualism, a pair of opposed ideas, forces, tendencies.

In historical writing, indeed in history itself, these dualisms abound. No-one, for example, can gain much sense of American history unless he sees »American» and »Europe» as a dualism, and not merely a couple of geographical designations. »America» and »Europe» function as polarities: as opposite terms in a tension between democracy and aristocracy, innovation and conservatism, the future and the past. Within the United States, »North» and "South» are likewise much more than geographical labels. They are resonant with argument and antagonism. They symbolize antipathetic attitudes. »North» stands for a polyglot, mobile, urban, industrial society: a "Yankee» society. "South» stands for a more homogeneous, static, agrarian, planter-and-slave society: a »Cavalier» society.

On a smaller scale, we find that in the saline way American military history seems to fall into a persistent dualism. On the one side there is the »professional» or »regular» principle, with the 
U. S. Military Academy at West Point as its particular symbol. On the other side there is the wamateur», or »volunteer» or "citizen» soldier, symbolized by the militia, and in particular by the »Minutemen» who rushed from their ploughs to confront the British redcoats at Lexington and Concord in 1776. These two opposing principles, the professional and the amateur, have a long tradition of mutual hostility - and of course not only in the United States. The professional soldier thinks of the amateur as - at best - amateurish; and, at worst, as a meddler, an intriguer, a person who owes his place in the army to political influence. In his own eyes the professional soldier is, by definition, a man above politics. Politics is an unscrupulous, civilian activity which he ignores and despises. In the words of a British general of seventy years go (Lord Baden-Powell, the founder of the Boy Scout movement): »From what I know of them, I would not trust an ordinary politician with my grandmother's toothbrush.» By contrast the citizen soldier, or the politican interested in military affairs, regards the regular soldier as - at best - conventional, slowmoving, clannish; and, at worst, as a person of inordinate vanity, tempted to use his momentary power or popularity to break in upon the civilian sphere of authority.

Two books sum up this long-standing American rivalry, both written in the aftermath of the American Civil War. One, entitled The Military Policy of the United States, is the work of a professional soldier, a graduate of West Point, named Emory Upton. Upton's thesis is that in all America's conflicts, including the Civil War, the professionals only just managed to avert the ruin threatened by civilian, and especially political folly. The other book, entitled The Volunteer Soldier of America, is by a politician-turnedamateur-soldier, John A. Logan. Logan's thesis is that in all America's conflicts, including the Civil War, the amateurs and politicians only just managed to avert the ruin threatened by the incompetence of the professional soldiers.

The interesting thing is that Upton's thesis has in the past halfcentury gained quite general acceptance among historians in the United States. Textbooks now commonly explain that in the Civil War, as in previous conflicts, the regular officers on the Norrhern (Union) side were bedevilled with »politics». It was because of political 
interference, we are told, that the much stronger Union armies took so long to defeat the South. Only when West Pointers were in control, and were trusted by Lincoln's administration, could the North sweep forward unhindered. The Union generals, it must be confessed, often said this at the time. One of them, David Hunter, declared in 1564 that »the United States governinent has nearly destroyed the vast resources of the people. Thousands and thousands of lives and millions of property have been sacrificed to the filthy demon of politics.,,

The filthy demon of politics!

One trouble with these dualisms - America versus Europe, North versus South, professional versus politician - is that trey tend to be seen also as a moral dualism: good versus bad, or even good versus evil. America thus becomes the repository of virtue, and Europe of vice. Another trouble is that, for contemporaries and for subsequent historians, they exercise a polarizing or magnetizing effect. Loose evidence, like loose iron filings, is drawn into one corner or the other in obedience to this oversimplifying pull. So, in speaking of »America» and »Europe», we have tended to exaggerate the »American» and »European» qualities belonging respectively to the two continents, and to ignore what »European» elements actually pertain also to the United States, or what »American» elements in fact pertain also to Europe. Similarly, we have tended to exaggerate the differences between North and South in the United States -- though of course in both cases the differences are real enough.

And, to come back to my subject, soldiers and politics in the American Civil War, we have tended to exaggerate the differences between the West Point professional and the ordinary American as General David Hunter did. Categories are neat; we could not get along without them. But history is an untidy affair, as I shall now illustrate in what I fear will be a most untidy discussion.

The Union army did have legitimate grievances against politics and politicians in the Civil War, at least according to its own lights. There were the initial and continuing senior appointments dished out to the Bankses, the Butlers, the Schenckses, the McClernands. There was the prodigious politiclring, at all levels, of the (predominantly) volunteer army: the elections within units to choose company 
officers, the power left in the hands of state governors to nominate field officers, the maneuvers of Congressmen to promote tlieir friends and demote their enemies. There was the constant interference with the formations fighting near to Washington. Given the muddled American military heritage, and his own consequent uncertainty, it is hard not to sympathize with the Union's general in chief McClellan in $1861-62$. Whatever his failings he behaved no worse, to say the least, than his predecessor Winfield Scott might have done in similarly trying circumstances. He was not the first or the last soldier to complain chat the dammed civilians were trying to run him. Those who came after, when matters were somewhat better regulated, still detested their proximity to Washington. John Sedgwick, as a corps commander under General George G. Meade, received a letter in November 1863 from an old lady which concluded: "May God preserve you from all dangers in the battle field and in the camp, and especially from commanding the Army of the Potomac.»Sedgwicli commented that from this last danger he was safe: »I know my name has been mentioned,... but nothing could induce me to take it. Meade is twenty years older than when he took command.»

Above all, regulars within reach of Washington - which in greater or lesser degrees meant most of them - had cause to fear and loathe the activities of the Committee on the Conduct of the War which Congress established in December 1861. Its terms of reference were sweeping. Its members were not only unversed in military affairs: they looked with suspicion on any soldier who had been at West Point. They were the spokesmen of the extreme, radical wing of the Republican party; the Committee's two Democratic members were largely ignored. The ferocity of the radicals is displayed in a typical subsequent utterance af one of the Committee, George W. Julian of Indiana:

Democratic policy, in the year 1861, gave us as commanders of our three great military departments McClellan, Halleck, and Buell, whose military administrations have so terribly cursed the country; while it impressed upon our volunteer forces in the field such officers as Fitz-John Porter, General Nelson, General Stone, and very many more whose sympathies with the rebels were well known throughout the country... 
Porter and Charles Stone were of course regulars. William (»Old Bull))) Nelson was a former naval officer — obligingly removed from the Committee's list by an aggrieved comrade who shot him dead in September 1862. Julian went on:

Of the major-and brigadier-generals in our armies Democratic policy has favored the Republican administration, if I am not mistaken, with over four-fifths, - certainly an overwhelming majority; while those great hives of military patronage the Adjutant-general's Department, the Quartermaster's Department, the Commissary Department, the Ordnance Department, and the Pay Department are all under Democratic control and have been during the war.

Senators Benjamin F. Wade, and Zachariah Chandler, Representative Julian and the other prime movers on the Committee, were supported by a good many members of Congress, by influential newspapers such as Greeley's New York Tribune and Raymond's New York Times, and by a large section of the public. They regarded Lincoln as weak, evasive, and lukewarm on the slavery issue. They convinced themselves that the army, thanks largely to West Point, was beset with apathy and defeatism, and that any officer known to be a Democrat was guilty of these sins until proved innocent.

Stanton shared their creed, and gave audience to Wade and Chandler every day that Congress was in session. Tt was Stanton who clapped General Charles P. Stone under arrest, and then denied him a fair hearing, after the fiasco at Ball's Bluff which led to the establishment of the Committee. Its members, eager to believe the worst, decided that Stone was guilty of treasonable relations with the enemy, and harried an innocent man into ignominy and imprisonment. Stone was released after six months and served again, but never in positions of responsibility. After the war he was almost a man without a country. His wanderings took him to Egypt, where he became chief of staff of the Khedive's army. Pasha Stone eventually returned to the United States and in his closing days, with an irony that cannot have been lost on him, was entrusted with the construction of the padestal for the Statue of Liberty in New York harbor.

The Committee treated other suspect generals with the same scant ceremony. Witnesses appeared alone, sometimes to find they 
were being interrogated by only one or two mombers of the Committee. Relevant testimony was withheld; they did not know whether they were merely witnesses, or whether like Stone they had been selected as victims. At least, soldiers who were under suspicion of »disloyalty» were handled in this fashion; the Committee maintained a dossier of the known or supposed political views of senior officers. It opposed the promotion or recommended the dismissal of men who did not meet its requirements. The Committee was by contrast heavily biased in favor of » reliable» citizen-soldiers such as Benjamin Butler, Lew Wallace and John C. Frémont. It encouraged officers thought to be radical in sentiment, planned military policy so as to push these officers forward, and thus helped to split the army into rival factions by setting one commander against another.

In vain might McClellan protest that his Democratic leanings held no military significance. As the spring of 1862 approached without apparent signs of haste on his part, the Committee grew almost morbidly suspicious. His plan to withdraw from the Washington front and advance on Richmond from the east, by way of the James Peninsula, struck them as not merely weak but possibly treacherous. At their insistence Lincoln ordered McClellan to regroup the twelve divisions of the Army of the Potomac into four corps under the senior division commanders, Irvin McDowell, S. P. Heintzelman, E. V. Sumner and Erasmus Keyes. The first three men had voted against McClellan's scheme at a previous conference, while Keyes had supported it only with reservations. All four, moreover, were considered $\gg$ radicals», whereas the other divisional commander - now to be their juniors - were for the most part politically »conservative», and strong supporters of McClellan. The immediate defenses of Washington were placed under the command of a political appointee, Brigadier-General James S. Wadsworth of New York. Another political general, Nathaniel P. Banks of Massachusetts, was to be entrusted with a separate corps created from the forces in the Harper's Ferry-Shenandoah Valley area. The radicals and Stanton also convinced Lincoln that McClellan had unduly weakened the defensive line covering Washington. On their urging he decided to withhold McDowell's corps from McClellan's Peninsula expedition. It is conaeivable that the Com- 
mittee may have had ulterior, party motives, akin to those of President Polk in the Mexican War. According to this theory, the radicals did not believe that the capital was in serious danger: they hoped to give their man McDowell a chance to dash forward and capture Richmond while McClellan was embroiled elsewhere with the main Confederate army.

The Peninsula campaign proved inconclusive. The radicals then backed John Pope, and ensured his promotion over McClellan in the summer of 1862. The defeat at Second Bull Run destroyed most of Pope's glamor, but he was let off lightly. Popular hostility was directed instead at Fitz John Porter, a warm admirer of McClellan. Porter, serving as a corps commander in the Bull Run battle, was denounced by Pope and by McDowell (another corps commander). Accused of deliberately sabotaging Pope's maneuvers, Porter was found guilty at a court-martial arranged by Stanton, and cashiered. This miscarriage oh justice, on a level with the deplorable treatment of General Stone, was not finally corrected until 1886.

The Committee's desire for vengeance was aroused by the further Union defeat at Fredericksburg in December 1862. ${ }^{1}$ Four Committee members descended on the camp of Pope's successor, Ambrose Burnside, to collect testimony. Burnside was a friend of McClellan. Rut he escaped their wrath by revising his opinions: he assured his inquisitors that far from condoning slavery he was working to end it. Reassured that Burnside's heart, and so presumably his head, was in the right place, the Committee sought another scapegoat for the Fredericksburg disaster. They found an acceptable victim in one of Burnside's generals, William B. Franklin. Though Franklin was more fortunate than Stone or Porter, he was never again given an important command. Once a highly regarded professional, he resigned from the army in despair in 1866.

Committee members were, following the familiar pattern, lenient with General Joe Hooker, a fellow-radical; they allowed him to escape censure after his inglorious performance at Chancellorsville in May 1863. They were less inclined to look kindly upon Hooker's

1 Politics of another sort may have been involved in the removal from their commands in November 1862 of McClellan, Porter and Buell, all Democrats. Their fall was not announced until after the mid-term Congressional elections. Warren G. Hassler, McClellan: Shield of the Union (Baton Rouge, 1967), 314 -322 . 
successor George Meade (a conservative). Though they could not demand Meade's dismissal for his generalship at Gettysburg in July 1863, they criticized his subsequent slowness and gradually began to hound him: hence the force of Sedgwick's remark that »Meade is twenty years older than when he took command.," They were not sure what to make of General Grant. Then he too incurred their displeasure for the inconclusive and bloody Wilderness campaign of 1864, and they urged the President to add Grant's name to the dismal roll of rejected generals.

There could well have been a committee to investigate the conduct of the Committee on the Conduct of the War. Or so some of the Union's luckless generals might have felt. There was some substance, along with exaggeration, in the comment of the London Times that America's Jacobins were repeating the extremist tendencies of the French Revolution: „The denunciation is precisely the same as those launched against the Girondins by the Mountain in the old French Convention. Disasters in the field have divided the Republican Party, and the zealots impute the reverses, not to the want of generals able to win victories, but to lack of faith in a principle.,, Vigilantism was rife. But then, the crisis was acute; and not all the faults were on one side.

This was, to reiterate, a civil war, with some of the elements of a revolution. In the confusion, opportunities for corruption abounded; it is hardly surprising that the venal side of politics - bribery, toadying, influence-peddling - flourished. Yet many Americans regarded politics in a higher spirit. It was one of the mechanisms which might enable the Union to wrest victory out of dire emergency. The New Yorher George Templeton Strong, an active member of the Sanitary Commission, recorded in his diary an argument at the Union League Club, shortly before the 1864 presidential election. The Club had drawn up a resolution that its duty was to use its influence to promote the re-election of Lincoln. A few members objected on the ground that this would convert the Club into a »mere political machine,,. Strong exploded:

A »mere political machine,, indeed! What subject of human thought and action is higher than politics, except only religion? What political issues have arisen for centuries more momentous 
than those dependent on this election? They are to determine the-destinies ... of the millions and millions who are to live on this continent for many generations to come.

Politics was in this sense far more than a cynical game. The crisis was deeper and deadlier in its divisiveness than that of the Mexican War. The response was inevitably more alarmist. If the Congressional radicals exceeded the proper limits of their authority, so by normal standards did the President - by expending money without previous sanction, by suppressing newspapers and arresting civilians. Accusation and counter-accusation were therefore virulent in the extreme. Stanton and the Committee on the Conduct of the War suspected McClellan of treasonable sloth: McClellan in his memoirs charged Stanton with »treasonable conspiracy».

Even for those who behaved more coolly, political could not be separated from military issues. Should the war be pressed hard against the South? Against all parts, or against certain regions? Should the border states be treated gently, in order not to drive them into the Confederacy? What should be done about slavery, not merely in the abstract but as a practical and urgent problem facing Union commanders? Should they respect Southern property, and return escaped slavers to their owners? Or should they treat the runaways as »contraband of war» (Butler's solution), or declare them liberated (Frémont's view)? Should the aim be to reach a settlement with the South and seek a swift end to the fighting, or to shatter the slavocracy as the only sune means of reconstituting its social base? Should Northern morale be sustained by the avoidance of heavy casualties, or by waging aggressive warfare? There was unanimity neither in the government nor in the army on such thorny and fundamental questions.

From the standpoint of energetic Union men, a number of propositions seemeed incontrovertible. The training of regular soldiers, in this view, made them too deliberate, too fortification-minded. Second, regulars were by training and association committed to a warped idea of the Union. The annual Boards of Visitors had kept on assuring the American public that West Point imbued cadets with a love of the Union. But a large number of West Pointers had joined the rebellion. The affection they appeared to show was for one another: an affection that made Northern West Pointers 
reluctant to strike hard against their Confederate fraternity. ${ }^{2}$ Hence the recurrent rumor that such-and-such a Union general, under cniticism for sluggishness, had actually slipped across the lines to consort with the enemy commander. In the third place, it was assumed that most Democrats were untrustworthy, and could only exculpate themselves - like Benjamin F. Butler - by displaying the fanaticism of the newly converted. A Democrat was a potential Copperhead; some Democrats, such as Marble Manton, editor of the New York World, were reganded as vicious traitors. It followed, fourthly, that the most dangerous of Union commanders was a West Point graduate who admitted to being a Democrat and who had close social or family ties with the Confederacy. Acconding to this rough yet not entirely absurd formula, several Union commanders were objects of legitimate suspicion. Don Carlos Buell, for example, was a cousin of old Daniel Twiggs, the general who surrendered the Department of Texas to the Confederacy in 1861 and then joined the rebellion. George Meade was the brother-in-law of the Confederate general Henry A. Wise, the former governor of Virginia.

Such prejudice was not confined to Northern radicals. Indeed the very term »radical» is misleading. The Committee on the Conduct of the War was not the only voice of vehement Republicanism. Secretary of War Stanton was at least as implacable as the Committee. Lincoln, though attacked by extreme antislavery men as weak and conservative, was himself impatient with McClellan and other generals who seemed to be dragging their feet. So was his Secretary of the Treasury, Salmon P. Chase, who was not much impressed by Stanton or Lincoln. Though the reports of the Committee no doubt inflamed public opinion, members of the public such as G. T. Strong were already disposed to share their restless inquisitorial attitudes. After the defeat at Fredericksburg Strong expressed his fear that $\gg$ Franklin and many of his brethren are, like the late General Fitz-John Porter, bad cases of blood poisoning and paralysis from hypertrophied McClellanism». As late as November

2 The Radicals would have been angered but not surprised if they could have read the diary-entry for 6 May 1861 of the retired soldier Ethan Allen Hitchcock: "Many friends urge my return to the army. But I have no heart for engaging in a civil war... If fighting could preserve the Union (or restore it) I might consider what I could do to take part - but when did fighting make friends?, Fifty Years in Camp and Field, 430. 
1864, Strong was still an enthusiastic admirer of Benjamin Butler. Butler might not have won brilliant victories: the important thing was that he was a true Union man, a »terrier» well able to deal with Coppherhead »rata».

The Committee, in other words, typified a fairly widespread Northern viewpoint. To see this as a contest between Republican zealots or intriguers and hapless West Pointers is to distort and oversimplify. Not all »political» generals were upheld: though the loyalty of N. P. Banks was not considered doubtful, he became as unpopular with the Committee on miltary grounds as were certain of the regulars. Nor were the regulars uniformly castigated. The Committee, in common with many American civilians, refused to accept the claim that professional training was an essential prerequisite for generalship. But at various times it eagerly urged the claims of regulars deemed to be of the right stamp: William $\mathrm{T}$. Rosecrans in the West, McDoweell, Pope and Hooker in the East.

Possibly the regulars were contaminated by the political atmosphere. One may argue that they were forced into partisanship by the realization that the only chance of promotion, and sometimes of survival, lay in a real or apparent conversion to radicalism. Similarly, one may contend that as in the Mexican War, the more prominent generals were forced into political awareness by being openly discussed as presidential timber. This could be seen as McClellan's fate, when he became the somewhat reluctant Democratic nominee in 1864. Certainly political strategists knew that any general who achieved conspicuous success in an important command, especially in the East, was automatically entered for the presidential stakes. Lincoln's famous letter to Hooker oh January 1863, appointing him commander of the Army of the Potomac, may be interpreted in this light. Lincoln praised Hooker as one who did not »mix politics with your profession». He went on:

I have heard, in such a way as to believe it, of your recently saying that both the Army and the Government needed a Dictator... Only those generals who gain successes, can set up dictators. What I now ask of vou is military success, and I will risk the dictatorship.

A letter full of the humorous sagacity for which Lincoln is justly 
admired.Yet it is also a sharp warning to Hooker not to meddle with president-making, on the assumption that he is very likely to be impelled to do so if he gains a victory. A few months later, when a successor to Hooker was being sought, the administration may have been stimulated to prefer Meade to John F. Reynolds on the ground that Meade, having been born abroad (his father was in the consular service), was thereby disqualified from becoming a presidential possibility. In 1864 Grant was being boosted for the White House; the New York Herald acclaimed him as »the man who knows how to tan leather, politicians and the hides of rebels,,. According to one account Lincoln delayed naming Grant to the command of the Union armies until he received an assurance - via J. Russell Jones, the U. S. marshal in Chicago and a confidant of Grant's - that the general had no intention of trying for the presidency, despite the encouraging chorus from Democratic newspapers.

Grant, and Sherman, were unusual among Union commanders in their distaste for political intrigue. This is not to say that they had no awareness of political nuances. Grant was after all only renouncing his chance of nomination for the coining election of 1864 . The next time rotund, 1868, he was in fact the Republican candidate. Even in 1864 he could hardly fail to realize how much was at stake in Lincoln's campaign for re-election. $\mathrm{He}$ and other generals responded readily to the administration's appeal to send soldiers home on leave to sway the vote in doubtful states. Some states allowed their soldiers to vote in the field. Wether or not generalsacquiesced, there is evidence that these votes were rigged to ensure Republican victory. Grant despatched a telegram to Lincoln the day after polling to inform him that the Sixth Corps had turned in a Republican majority of over twenty thousand. One biographer of Grant, citing the telegram, adds: »he was practically Jim Farley. ${ }^{3}$ " Not quite; still, the point is worth making.

Most Union generals, through whatever mixture of conviction and self-interest, displayed rather than disguised their political leanings. Burnside, Halleck, Hooker, McClellan, Rosecrans, Sherman, Stone and Grant were among the regulars who had left the army before

3 Postmaster-general in Franklin D. Roosevelt's cabinet, and a totally professional politican. 
the war. Some of them - including McClellan, a railroad executive and a Douglas Democrat - had quite well-defined political opinions. Ambrose Burnside, who resigned his commission in 1853, had run unsucceessfully as a Democratic candidate for Congress in Rhode Island before joining his friend McClellan in the Illinois Central. In the growing sectional crisis they could not help but form »views» - views which as civilians they were perfectly entitled to hold and express. Hooker, who also resigned in 1853, had particular reasons to regard himself as a civilian. He had taken Pillow's side in the Pillow-Scott controversy during the Mexican War.

When he first offered his services to the army in 1861 he was snubbed by the War Department. The most plausible explanation was that he was being victimized by General Scott's regular suborinates. A number of serving regulars held ar developed firm political convictions.

So while the Committee on the Conduct of the War may be blamed for forcing political alignments upon the Union generals, it cannot be said that the soldiers themselves were utterly apolitical. Their first appointments to the Military Acedemy were determined by Congressional, i.e. political, nominations. Their places in the army as commissioned officers were often secured by lobbying friends in Congress. Those who graduated high on the list at West Point went into the Corps of Engineers and were commonly employed on government construction schemes. Several officers actually worked for long periods in Washington on these semi-civilian tasks, and developed close links with Senators and Representatives. During the Civil War they bombarded Congressmen and the Administration with requests for promotion, for leave, for special consideration of every kind.

As we have noted, McDowell, Pope, Hooker, David Hunter and others declared themselves to be radical. McClellan insisted in his memoirs that he was innocent of political ambition. No doubt this was true at the outset. Yet despite himself he followed the path of Winfield Scott. He was a hero; he began to believe what he was told be his admirers, or by people who shared his resentment at the Republican administration - that he was agenius whose country needed him at the head of its counsels. Once he was sufficiently famous he was automatically a candidate for the presidency. As with Scott, 
his very fall from favor not only spurred his ambition and rancor but also made him the more attractive to the opposition party.

The most balanoed assessment of the situation is that of the situation is that Jaaob Dolson Cox. This Ohio politician, who became a major-general and a corps commander, was a former brigadier-general af militia. Though he had never worn uniform in peacetime he claims to have long been interested in tactics and strategy. The volunteer battalions had, he concedes, many defects; they often went wrong, for example, in their initial choice of afficers. But the worst errors were remedied, and the mass of young volunteer officers showed both ability and adaptability. As for the so-called »political generals, he wisely remarks:

In an armed struggle which grew out of a great political contest, it was inevitable that eager political partisans should be among the most active in the new volunteer organizations. They called meetings, addressed the people to arouse their enthusiasm, urged enlistments, and often set the example by enrolling their own names first... It was a foregone conclusion that popular leaders of all grades must largely officer the new troops.. . It was the application of the old Yankee story, "If the Lord will have a church in Paxton, he must take sech us ther' be for deacons.

Cox admits that in a sense $\gg$ the whole organization of the volunteer forae might be said to be political," but that "we heard more of 'political generals' than we did of political captains or lieutenants». The inifusion of politics at all levels, from the narrow matter of party patronage to the broadest and highest matters of Union policy, was thus not merely inevitable but even desirable.

On the question of patronage appointments, the West Point complaint was that senior commands were entrusted to men of no military talent, some of whom had got in by the door marked »push» and some by the door manked »pull». Could anything be said in praise of a Banks or a Butler, a McClernand, a Daniel Sickles, a Franz Sigel, or (on the Confederate side) a Gideon Pillow, a Hotell Cobb or a Felix Zollicoffer? The most obvious answer is that Lincoln (and Davis, to a lesser extent) were obliged to appoint such men, or to accept them on pressing recommendation. There were not enough West Pointers to go round. Lincoln needed Sigel 
because Sigel was German-born and a leader in the St Louis community. As such he was a valuable bellwether for German-Americans: »I fights mit Sigel» was said to be their slogan. Moreover, Sigel was a graduate of a military academy and had served in the German army. He had been active in the militia since he arrived in the United States. It was reasonable until events proved otherwise to assume that Sigel might be another Steuben or de Kalb. Benjamin Butler's pre-war militia experience, his energy and confidence, and his standing as a War Democrat, made him too important to be brushed aside. Banks, a former Congressman and governor of Massachusetts, sounded like a politico and had a somewhat unimpressive war record, culminating in his resignation after the Rod River fiasco in 1864. But he was a man of courage who held a series of thankless commands, and who had some grounds (like General John A. Logan, the former Democratic Congressman from Illinois) for believing that he was discriminated against by a West Point coterie. James S. Wadsworth was a radical Republican who interrupted his military service to run unsuccessfully for the governorship of New York: he was also a gallant leader who returned to the army, commanded a division at Chancellorsville and Gettysburg, and was mortally wounded in the Wilderness in 1864. The overriding fact, as Butler and Logan were to insist in later years, was that long before the end of the war every important command was in the hands of a regular soldier. The most that $\gg$ political» or $\gg$ civilian» soldiers could hope for was a subordinate role, or command of an unpromising sideshow like the Red River campaign. In other words, the professionals had no more reason to complain of this political feature of the war than of radical efforts to determine strategy.

The Committee on the Conduct of the War did behave arbitrarily. But insofar as there was a »West Point mentality», the Committee and its supporters were not entirely wrong to equate this with sluggishness. Though the wrong men - Buell, Porter - may have been hounded, there was a case for punishing a few commanders pour encourager les autres. Insofar as the West Pointers shared the same uncertainties and prejudices - including political ones - as the rest of their countrymen, the Committee was not entirely wrong in treating them accordingly. 
While there was therefore a kind of esprit du corps among regulars, before and during the Civil War, its effects were limited. The professionals sometimes thought of themselves as an entity when they were threatened as an entity by outsiders, or believed they were. Their chief complaint was against politics and politicians because these were convenient shorthand terms. »Politics» covered a multitude of actual or fancied forms of neglect, ingratitude, injustice, disappointment. Like soldiers in other armies, who have looked forward to peacetime »in order to get back to real soldiering», they attributed to the military sphere everything that was simple, clear, honest and heroic, and to the political sphere everything that was tangled, discordant, frustrating and treacherous.

They were in fact, of course, far from united on most issues. In the Civil War the Union seemed at moments to be more at war with itself than with the Confederacy. They bickered over minor points, they split wide apart on the major issues of the war. Their factious quarrels spilled out in courts of inquiry, courts martial and even occasional duels. They were following the confused tradition of American civil-military relations.

The regular officers were then not a caste apart, absorbed in their craft and unaware of political contexts. It must be added though that their behavior was as a whole healthily strident. As a series of articles in the Army $\&$ Navy Chronicle of $1836-37$ had revealed, there were at last two sides to the problem of the involvement of soldiers in politics. The pure, apolitical professional was apt to be too much cut off from the life of his country. He could degenerate into the outlook of a mercenary. Or, through disdain and conceit, he could conceive of himself as a privileged and powerful janissary. At the other extreme, the too-thoroughly civilianized soldier was equally dangerous: non-military factors played too large a part in his thinking.

Both of these extreme tendencies could be seen in other countries. The United States has not had »men on horseback, though it has had a number of generals in the White House. Among presidential aspirants, only the semi-civilian soldiers have carried the day. Those with vainglorious, proconsular temperaments have failed to satisfy the electorate. The public has, to use a distinction drawn by Arthur Schlesinger Jr., preferred the »Ikes» to the »Macs» - Taylor to 
Scott, Grant to MoClellan. Bearing in mind the deficiencies of Scott and McClellan, we may be glad that Democratic intrigue ruined the chances of the one, and Republican intrigue the chances sf the other. If Polk and Lincoln, and their henchmen, had acted with high-minded generosity toward these contenders, it is conceivable that both might have gained the presidency. It is almost certain that they would have made bad presidents. It is however also almost certain that neither would have indulged his grandiose egotism to the extent of subverting the Constitution. Though their heads were turned by ambition and flattery, they were still sane. In the 1860s there was a great deal of talk in the North, among soldiers and civilians alike, of the need for a strong man, a leader, a Cromwell, to save the Union. The need remained a matter of talk. None of the putative Napoleons took any positive step to assume control. When challenged the men on horseback were quick to dismount. There was no real threat of a coup d'etat. None went even as far toward power as France's abortive hero of the 1870s, General Boulanger.

Neither before nor during Civil War did America solve the problem of how to steer neatly between the extremes of civilianness and militarism. But then, no other country has discovered the exact range of appropriate compromises. This is a problem without a perfect solution. The American answer leaned toward civilianness. In the words of »Alcibiades», writing in the Army $\mathcal{E}$ Navy Chronicle in January 1836:

If a military officer feels no interest in the important political struggles of the day, ... he acknowledges himself at once to be.. a hireling... who would serve the Russian Autocrat, the British King, or even Louis Philippe, provided the pay and rank were sufficient temptation.

Nearly every officer of any distinction, at the commencement of the American Revolution, was a politician... Politics filled our early councils with those who had... wielded the sword against the enemies of liberty... Look to the late war with England! Were not many of the most distinguished officers of that period politicians, most of whom still live to prove the truth of the assertion?

The West Pointers were professional to the extent that they thought themselves better than amateurs, and gave preference to 
their own kind where they had the opportunity, as Sherman did in picking O. O. Howard rather than John A. Logan to command the Army of the Tennessee after the death in action of James B. McPherson. Otherwise they were quite deeply immersed in civilianness. If they had not been, perhaps fewer would have abandoned the Union and gone over to the Confederacy. But their critics were Inconsistent in reproaching them simultaneously for being an aristocratic coterie and for responding so representatively to the emotions that swayed their fellow-countrymen. Many of the professional politicians were amateur soldiers. Many of the professional soldiers were amateur politicians. The interfusion made things chaotic: it helped to prevent them from becoming catastrophic.

\section{USA IN FOCUS}

containing articles and lectures from the

Nordic Association for American Studies' conference in Oslo: »American Civilization: Recent Re-interpretations>>; some remaining copies sold out at reduced price (sv kr 10:-).

Order to

\section{SECTION OF AMERICAN HISTORY}

S:t Larsgatan 2

$\begin{array}{lll}752 & 20 & \text { Uppsala }\end{array}$

Sweden 